\section{Prehistoric copper from the Eastern Alps}

\author{
Joachim Lutz, ${ }^{1}$ Ernst Pernicka ${ }^{1,2}$ \\ ${ }^{1}$ Curt-Engelhorn-Zentrum Archäometrie \\ gGmbH, Mannheim; ' ${ }^{2}$ niversität \\ Tübingen, Institut für Ur- und \\ Frühgeschichte und Archäologie des \\ Mittelalters, Tübingen, Germany
}

\section{Abstract}

The rich copper ore deposits in the Eastern Alps have long been considered as important sources for copper in prehistoric Central Europe. It is, however, not so clear which role each deposit played. To evaluate the amount of prehistoric copper production of the various mining regions it was attempted to link prehistoric metal artefacts with copper ores based on the geochemical characteristics of the ore deposits that have been exploited in ancient times. More than 120 ore samples from the well known mining districts Mitterberg, Viehhofen, Kitzbühel and Schwaz/Brixlegg have been analysed so far (lead isotope ratios, trace elements). Furthermore, about 730 archaeological copper/bronze artifacts were investigated and analysed. These results were combined with analytical data generated by previous archaeometallurgical projects in order to compile a substantial database for comparative studies. In the Early Bronze Age, most metal artifacts were made of copper or bronze with fahlore impurity patterns and most finds from this period match excellently the fahlore deposits in Schwaz and Brixlegg. At the end of the Early Bronze Age, a new variety of copper with lower concentrations of impurities appeared. The impurity patterns of these finds match the ores from the Mitterberg district. In the Middle Bronze Age, this variety of copper Dominated while in the Late Bronze Age fahlores from Schwaz and Brixlegg experienced a comeback. The reason for this may be a decline of the chalcopyrite mines or a rising demand for copper which could not be covered by the chalcopyrite mines alone. The finds of the Early Iron Age are of similar composition and continue the traditions of the Late Bronze Age.

\section{Introduction}

In prehistoric times the copper deposits in the Eastern Alps were mined on a large scale. This is documented by numerous mines and remains of extractive metallurgy like furnaces and slags. Especially fahlores (tennantite- tetrahedrite) and chalcopyrite ores were mined and smelted and the metal produced was distributed over large distances. In the last years, substantial archaeometallurgical resarch has been carried out in the frame of the ongoing Special Research Program History of Mining Activities in the Tyrol and Adjacent Areas - Impact on Environment \& Human Societies (Oeggl et al., 2008) funded by the Austrian Fonds zur Förderung der wissenschaftlichen Forschung (FWF). There are several phases of copper production in the Eastern Alps distinguishable: an initial of extractive metallurgy at the end of the Neolithic and in the Early Bronze Age, an almost industrial copper production in the Middle and Late Bronze Age, and a decline of copper mining in the Early Iron Age.

The most important ore deposits in North Tyrol, Salzburg and Styria occur in a belt of paleozoic sedimentary rocks, the Greywacke Zone. Well known prehistoric mining areas belonging to this zone are (from west to east) Schwaz and Brixlegg in the lower Inn valley (Rieser and Schrattenthaler, 2000), the Kitzbühel district (Pittioni and Preuschen, 1937; Goldenberg, 2004), Viehhofen in the Glemmtal, the Mitterberg district south of Salzburg (Zschocke and Preuschen, 1932; Eibner, 1994) and further to the east mining districts in the Eisenerzer Alps and Lower Austria (Figure 1). In the past most geochemical and mineralogical investigations focused on the mining areas of Schwaz and Brixlegg due to their historical importance for metal production in more recent times beginning in the $15^{\text {th }}$ century AD. Contrary to these areas in North Tyrol, almost no modern analytical data [instrumental neutron activation analysis (INAA), laser ablation-inductively coupled plasma-mass spectrometry (ICP-MS), lead isotopes] were available from the other important mining areas mentioned above. We started sampling and characterisation of ores with the most important and well known copper ore deposits in North Tyrol and Salzburg, all belonging to the Greywacke Zone (Schwaz/ Brixlegg, Kitzbühel-Kelchalm, Mitterberg). From these deposits sufficient analytical data has been compiled in the last years to estimate their relevance in prehistory. Analyses of samples from Viehhofen and some other ore occurrences are in progress, but not finished yet.

In contrast, a substantial data base of analyses is available for mainly Late Bronze Age artifacts from North Tyrol, Salzburg and southern Bavaria which was compiled during a research project of the Volkswagen foundation (Sperber, 2004). Preliminary investigations on artifacts from the late Neolithic period also exist (Höppner et al., 2005). A larger number of chemical analyses of Early Bronze Age objects exist from southern Bavaria. These data were obtained with emission spectroscopy and com-
Correspondence: Joachim Lutz, Curt-EngelhornZentrum Archäometrie gGmbH, Besucheradresse D6, 68159 Mannheim, Germany.

Tel. +49.0621 .2938949 - Fax: +49.0621 .2938956$

E-mail: joachim.lutz@cez-archaeometrie.de

Key words: archaeometallurgy, provenance, Eastern Alps, copper, ore deposits.

Acknowledgments: we thank Michael Brauns, Bernd Höppner and Thorsten Schifer (all CurtEngelhorn-Zentrum Archäometrie, Mannheim) for carrying out isotope and neutron activation analyses. We are also indebted to Gerhard Tomedi (Universität Innsbruck, Institut für Archäologien) and Walter Stephan (Museum Fliess) for access to prehistoric copper and bronze objects and to Robert Pils (Verein Montandenkmal Arthurstollen, Bischofshofen) and Franz Vavtar (Universität Innsbruck, Institut für Mineralogie und Petrographie) for supporting the field survey and sampling of ores. This project was funded by the Fonds zur Förderung der wissenschaftlichen Forschung (FWF), Vienna, Austria.

Citation: Lutz J, Pernicka E, 2013. Prehistoric copper from the Eastern Alps. In: RH Tykot (ed.), Proceedings of the $38^{\text {th }}$ International Symposium on Archaeometry - May $10^{\text {th }}-14^{\text {th }} 2010$, Tampa, Florida. Open Journal of Archaeometry 1:e25.

Presented at the $38^{\text {th }}$ International Symposium on Archaeometry - May $10^{\text {th }}-14^{\text {th }} 2010$, Tampa, Florida.

This work is licensed under a Creative Commons Attribution 3.0 License (by-nc 3.0).

(C) Copyright J. Lutz and E. Pernicka., 2013 Licensee PAGEPress, Italy

Open Journal of Archaeometry 2013; 1:e25 doi:10.4081/arc.2013.e25

piled during the research at the Württembergisches Landesmuseum Stuttgart (Junghans et al., 1964, 1968). From the Middle Bronze Age and Early Iron Age only few analyses have been published yet. It was the second focus of our research to analyse bronze objects especially from the Middle Bronze Age and the Early Iron Age to close these gaps in chronology and to compile a substantial database for the East Alpine region with analyses of finds from the beginning of metallurgy in the Neolithic up to the Early Iron Age.

\section{Geology and ore mineralogy}

The Greywacke Zone is an E-W trending belt of Paleozoic sedimentary rocks in the Austrian Alps between the Northern Calcareous Alps and the Central Eastern Alps. The unit consists of Paleozoic sediments (turbidites, greywackes 
and limestones) of Ordovician to Devonian age and of mafic volcanic rocks of Cambrian/Ordovician age. These rocks are relatively soft and prone to weathering. In the western Oberinntal Valley near the Arlberg Mountain, the Greywacke Zone forms only a narrow strip, but then widens to the east to include large parts of the Tux Alps, the Kitzbühl Alps and the Salzburg Slate Mountains. Further to the east it runs along the upper Ennstal Valley, the Eisenerz Alps and the Mürztal Valley. Numerous copper deposits occur in this sedimentary unit, related to mafic volcanism. The primary ore assemblage consists mainly of chalcopyrite and pyrite at the Mitterberg (Bernhard, 1965; Weber et al., 1971, 1972) on the one hand or fahlore at Schwaz/Brixlegg on the other hand (Gstrein, 1988, 1989).

\section{Sampling and analytical techniques}

More than 120 ore samples from the Mitterberg district, the Kelchalm near Kitzbühl, Viehofen and Schwaz/Brixlegg were analysed chemically by neutron activation analysis (NAA, for $\mathrm{Fe}, \mathrm{Co}, \mathrm{Ni}, \mathrm{Cu}, \mathrm{As}, \mathrm{Sb}, \mathrm{Ag}$, $\mathrm{Au}, \mathrm{Se}, \mathrm{Te}, \mathrm{Zn}, \mathrm{Sn}$ ) and inductively-coupled plasma mass spectrometry with a quadrupole ion filter (QICP-MS, for $\mathrm{Pb}, \mathrm{Bi}$ ). Furthermore, the lead isotope ratios were determined in some of the ore samples and in addition also in some slag samples from the Mitterberg district using multi-collector ICP-MS. About 730 prehistoric copper and bronze finds were sampled (drill samples) and analysed by X-ray fluorescence (XRF), selected samples also by NAA, QICP-MS and multi-collector ICP-MS (lead isotope ratios).

\section{Trace element and lead isotope patterns of the ores}

In the east Alpine Greywacke zone, two major types of copper ores are present: fahlores of the tennantite-tetrahedrite series $\left(\mathrm{Cu}_{12} \mathrm{As}_{4} \mathrm{~S}_{13}-\mathrm{Cu}_{12} \mathrm{Sb}_{4} \mathrm{~S}_{13}\right)$ and chalcopyrite $\left(\mathrm{CuFeS}_{2}\right)$ /pyrite $\left(\mathrm{FeS}_{2}\right)$ ores. These two types of ores are easily distinguished geochemically. The fahlores from Schwaz and Brixlegg are characterised by high concentrations of arsenic, antimony, silver and bismuth but low levels of cobalt and nickel (Figure 2). In contrast, chalcopyrite/pyrite ores from the Greywacke Zone (Mitterberg, KitzbühelKelchalm, Viehhofen) have relatively low concentrations of $\mathrm{As}, \mathrm{Sb}, \mathrm{Ag}$ and $\mathrm{Bi}$. Due to the presence of gersdorfitte and some other acces- sory minerals in chalcopyrite ores from the Mitterberg district, the concentrations of arsenic, cobalt and nickel are higher compared with the ores from Kitzbühel-Kelchalm (Figure $3)$. In contrast, the Kelchalm samples contain more bismuth and selenium than ores from the Mitterberg. There are also some differences in trace element concentrations between the Mitterberg veins. For example, the Brander lode contains more cobalt and nickel than the other veins (Lutz et al., 2009).
Lead isotope ratios of ores from the Greywacke Zone show a large variation (especially the Mitterberg main lode) due to low lead contents combined with occasionally high uranium concentrations. For this reason, it is difficult to establish a connection between metal objects and the deposits only with lead isotope ratios. The lead of syngenetic ores from the Mitterberg region (Winkel-, Buchberg-, Brander-, Burgschwaig- and Birkstein lode) and Kitzbühel-Kelchalm is less radiogenic

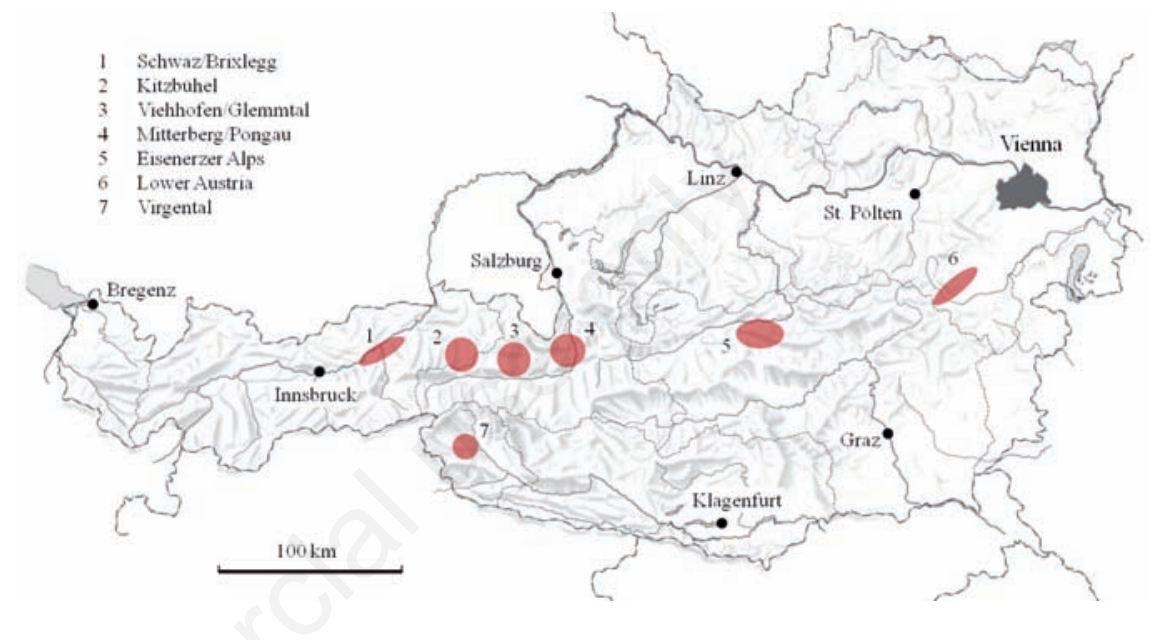

Figure 1. Prehistoric mining districts in the Eastern Alps.

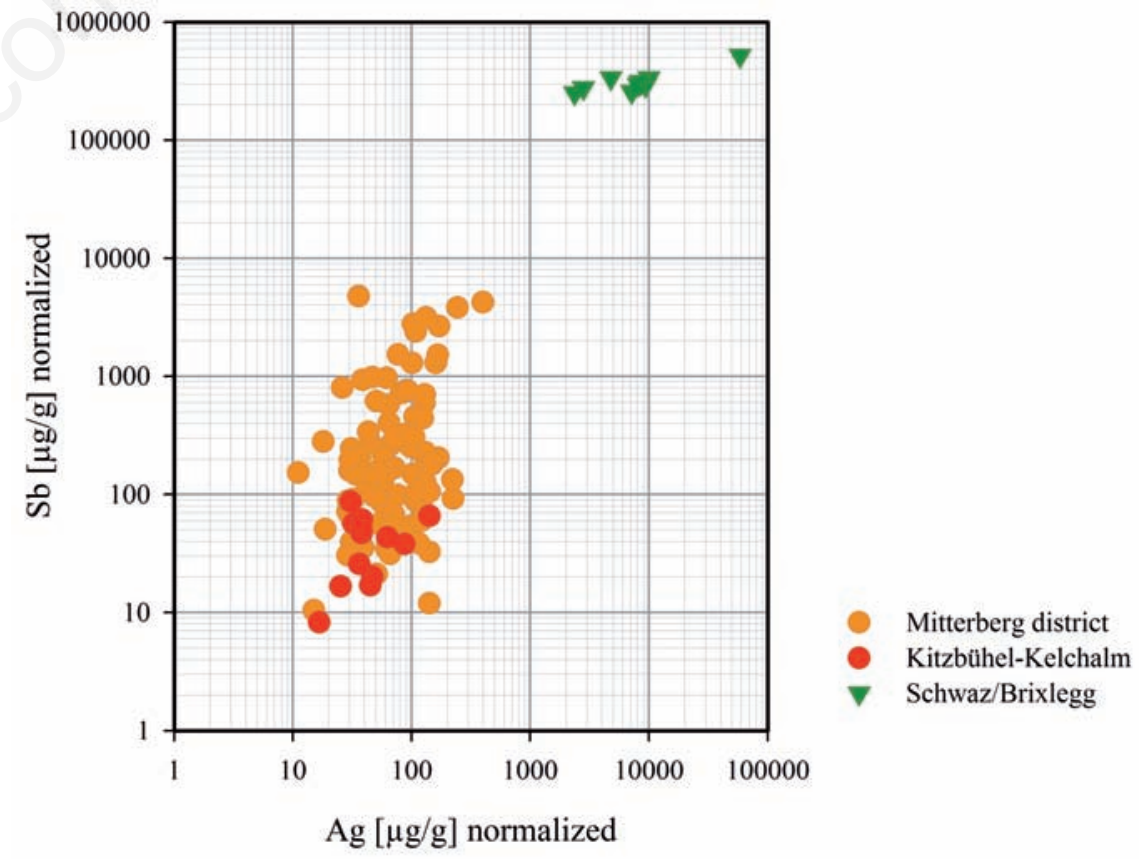

Figure 2. Ag/Sb-diagram of ores from the Mitterberg district, Kitzbühel-Kelchalm and Schwaz/Brixlegg. The fahlores from Schwaz/Brixlegg have always high concentrations of silver and antimony and can easily be distinguished geochemically. 
than lead of the epigenetic Mitterberg main lode (Figure 4A). The fahlores from the Inn valley can be differentiated from the ores of the Mitterberg by lower ${ }^{208} \mathrm{~Pb} /{ }^{206} \mathrm{~Pb}$ ratios (Figure 4B). In summary, we are now confident that the ore deposits that we have investigated until now can be differentiated geochemically by combining trace element concentrations and lead isotope ratios.

\section{Composition of Bronze Age and Early Iron Age metalwork and comparison with trace element/isotopic patterns of the ore deposits: examples from different periods}

\section{Kiechlberg (Late Neolithic and Early Bronze Age)}

The metallurgical remains from the Kiechlberg near Innsbruck excavated by the research group of Gerhard Tomedi and Gert Goldenberg (Institute of Archaeology, University of Innsbruck) have been investigated and analysed (Töchterle et al., 2010). Besides metal objects like daggers and awls, some fahlore-copper ingots were also found. The elemental composition of these ingots as well as the lead isotope signature matches the fahlores from the Inn valley, especially from the Brixlegg district. This proves that in the Early Bronze Age local metallurgy in the Inn-valley exists and ores from the deposits nearby were smelted.

\section{Hoard from the Moosbruckschrofen (Middle Bronze Age)}

This hoard with about 360 objects is the largest metal accumulation of the Middle Bronze Age in central Europe (Tomedi, 2001). All metal objects except some black copper ingots were made of bronze. The impurity patterns of the bronzes and ingots are relatively uniform. The fragments of black copper are most suitable for provenance studies because their geochemical fingerprint was not altered by alloying, mixing or recycling. The trace element analyses and lead isotope ratios of the blister copper and most of the bronze objects match the geochemical data of the ores from the Mitterberg. This result does not come as a surprise - the Middle Bronze Age is the period of peak production of copper in the Mitterberg region.

Late Bronze Age finds from southern Bavaria, Salzburg and North Tyrol

In the 1990 s, almost 800 prehistoric metal objects from southern Bavaria, Salzburg and northern Tyrol were analysed within the scope of an archaeometallurgical project funded by the Volkswagen Foundation (Sperber, 2004), including more than 70 bun-shaped ingots of black copper/fahlore copper. About one quarter of those match the geochemical data of the ores from the chalcopyrite deposits (Mitterberg, Kelchalm and Viehhofen). The impurity patterns of another quarter of the ingots correspond with the fahlore deposits of the Inn valley. In contrast to the ingots, most bronze objects show mixed impurity patterns. Mixing of copper smelted from chalcopyrite ores (low levels of impurities) and fahlore copper (high levels of arsenic and antimony) was probably done intentionally in order to reduce the high contents of arsenic and antimony to a tolerable level and to improve forgeability.

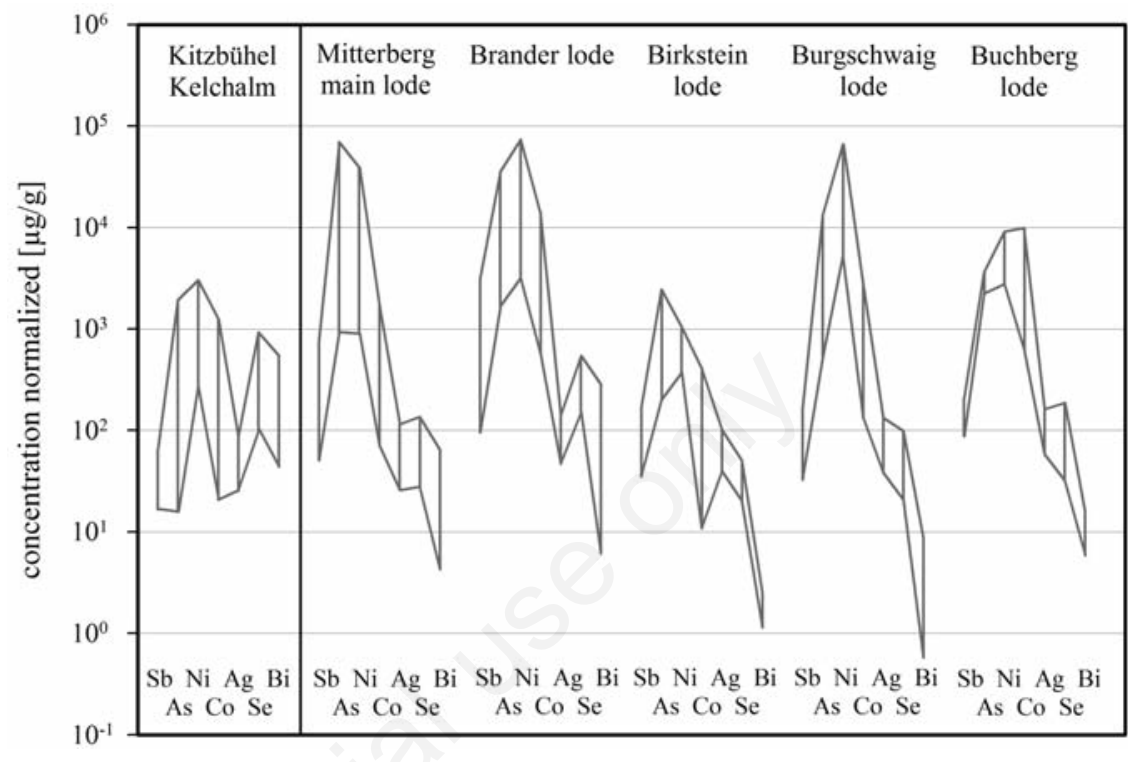

Figure 3. Trace element patterns in ores from the Kelchalm deposit and from the Mitterberg district (several different veins). The spread for some elements (Sb-As-Ni-Co$\mathrm{Ag}$-Se-Bi) is plotted on the Y-axis in the same order. The trace element signature of the Kelchalm deposit is clearly different from the Mitterberg veins.

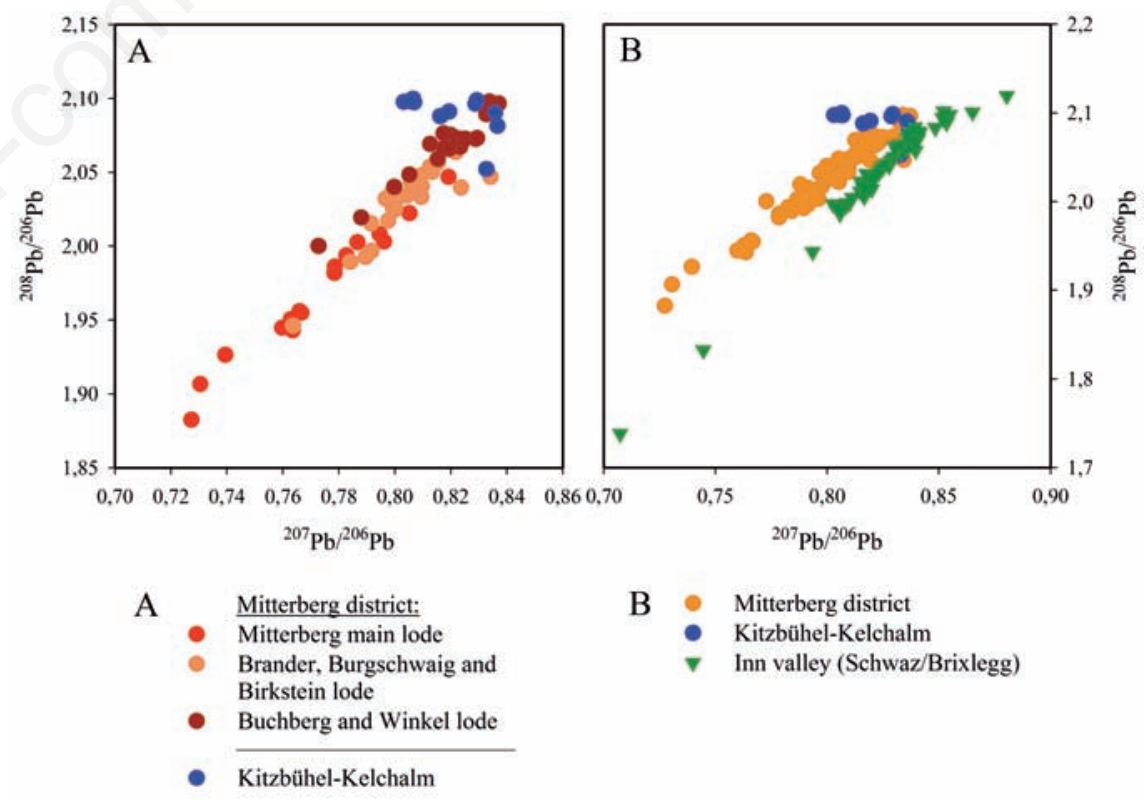

Figure 4. A) Lead isotope ratios in ores from the Mitterberg district and KitzbühelKelchalm. The ores from the epigenetic Mitterberg main lode is more radiogenic than the syngenetic ores from the other veins. B) Lead isotope ratios in ores from the Mitterberg district, Kitzbühel-Kelchalm and fahlores from the Inn valley (Schwaz/Brixlegg). The ores from the Inn valley are characterised by lower $208 \mathrm{~Pb} / 206 \mathrm{~Pb}$ ratios. 


\section{Early Iron Age hoard from \\ Fliess/Tyrol}

The impurity patterns of the Early Iron Age Early bronze objects are almost the same as in the Late Bronze Age. Most of those are also mixtures of copper smelted from chalcopyrite and fahlores. The spread of the elements is nearly the same, but some details are different. In the Early Iron Age lead contents are higher (median $\sim 0.5 \% \mathrm{~Pb}$ ). This raises the question, whether lead was added to improve the castability of the alloy or if it can be considered as an impurity of the ore. Since lead concentrations are correlated with the typical fahlore elements antimony, arsenic and silver, which should not be observed if lead was added, we conclude that lead is mainly associated with the copper component. The lead isotope ratios of the Early Iron Age bronze objects perfectly match the ores from the Brixlegg district. High lead (galena) contents are reported for several deposits in the Brixlegg district, namely Einberg, Hoferbau, Matzenköpfl, and Silberberg (Weber, 1997). Accordingly, these deposits were probably the sources of fahlore copper in the Early Iron Age.

\section{Long-distance trade relations}

In the years 1994-96, many Neolithic and Early Bronze Age metal objects from eastern Germany were analysed within the scope of an archaeometallurgical project funded by the Volkswagen Foundation (Early Metallurgy in Central Europe, FMZM, for a summary see Krause, 2003). This analytical work has found continuation in a project on the Sky Disk of Nebra, funded by the Deutsche Forschungsgemeinschaft (DFG). As a result of these projects, modern analytical data of metal finds is available from this region and can be compared with the geochemical data of the ores from the Eastern Alps.

\section{Fahlore copper of the Inn valley type (Early Bronze Age)}

The most common type of fahlore copper used in the Early Bronze Age in eastern Germany contains in the order of $1 \%$ nickel, which is unlikely to have been produced in the Inn valley. Less abundant is a nickel-poor variety, which matches the trace element and lead isotope patterns of the fahlore deposits of the Inn valley.

\section{The hoard of Nebra and the Sky Disk (end of Early Bronze Age)}

The trace element patterns of all objects of the Nebra hoard find an excellent match in the new data of the ores from the Mitterberg
(Figure 5A and 5B). Lead isotope ratios of the metal finds correspond very well with the slag samples from the Mitterberg area (Figure 5C and 5D). There is a marginal systematic difference between the lead isotope ratios of the ores and the slag samples. The reason might be a different lead isotopic signature of additional fluxes used in the smelting process or the separation of uranium phases and radiogenic lead while processing the ores (milling, washing).

These two examples show that metals from the Eastern Alps were distributed over large distances already in the Early Bronze Age.

\section{Conclusions}

\section{Relevance for prehistoric societies}

The trace element and lead isotope fingerprints of many Bronze Age and Early Iron Age metal artifacts correspond with the ores of the east alpine Greywacke Zone. Qualitatively, this has been suggested before but the present study confirms this suggestion on a quantitative basis. Accordingly, there can be no doubt that these deposits were an important, if not the most important, source for copper in prehistoric Central Europe.
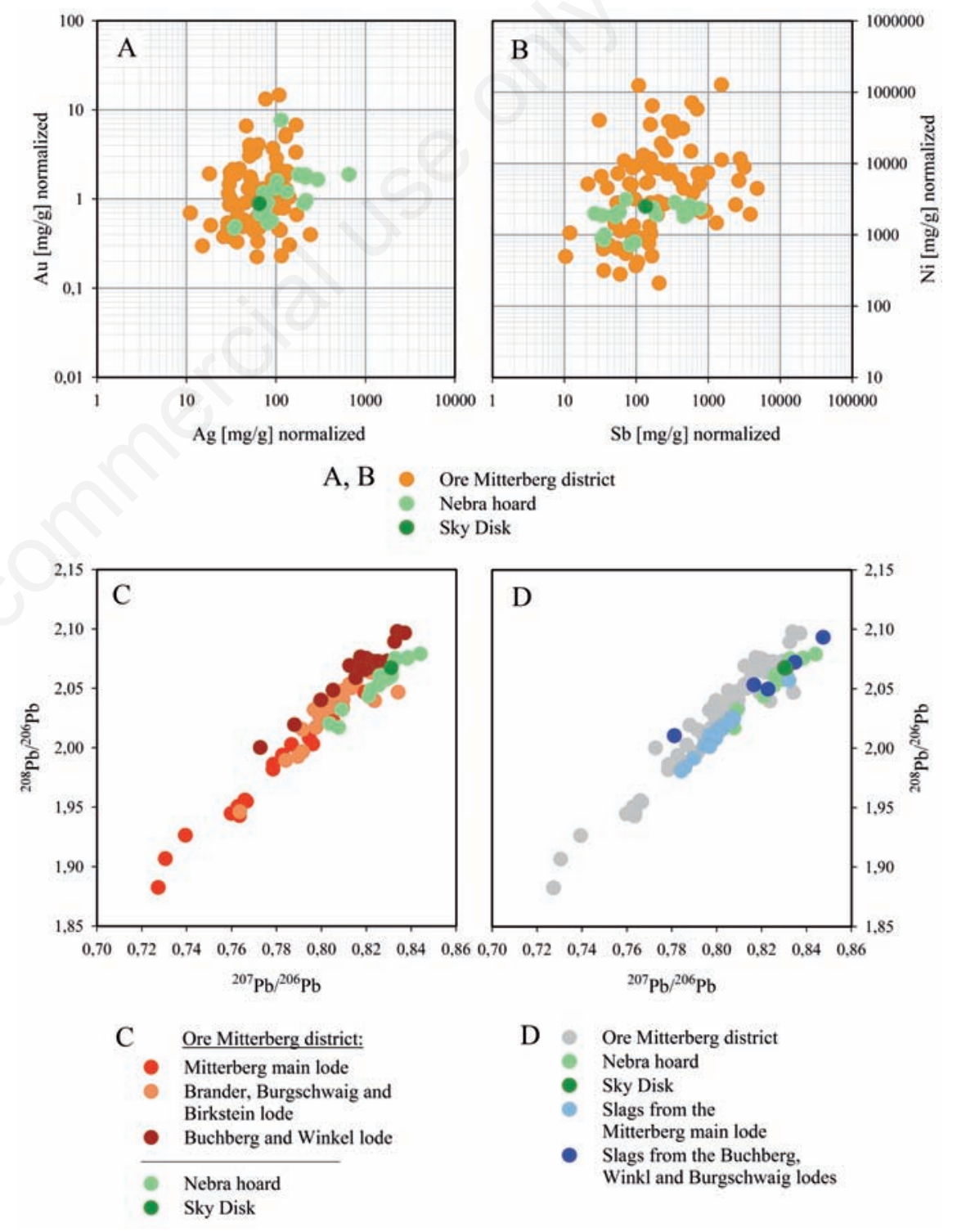

Figure 5. A,B) Trace elements in ores from the Mitterberg district and in findings from the Nebra hoard; C,D) lead isotope ratios in ores and prehistoric slags from the Mitterberg district compared with the Nebra hoard and the Sky Disk of Nebra. 
Goldenberg G, 2004. [Ein Verhüttungsplatz der

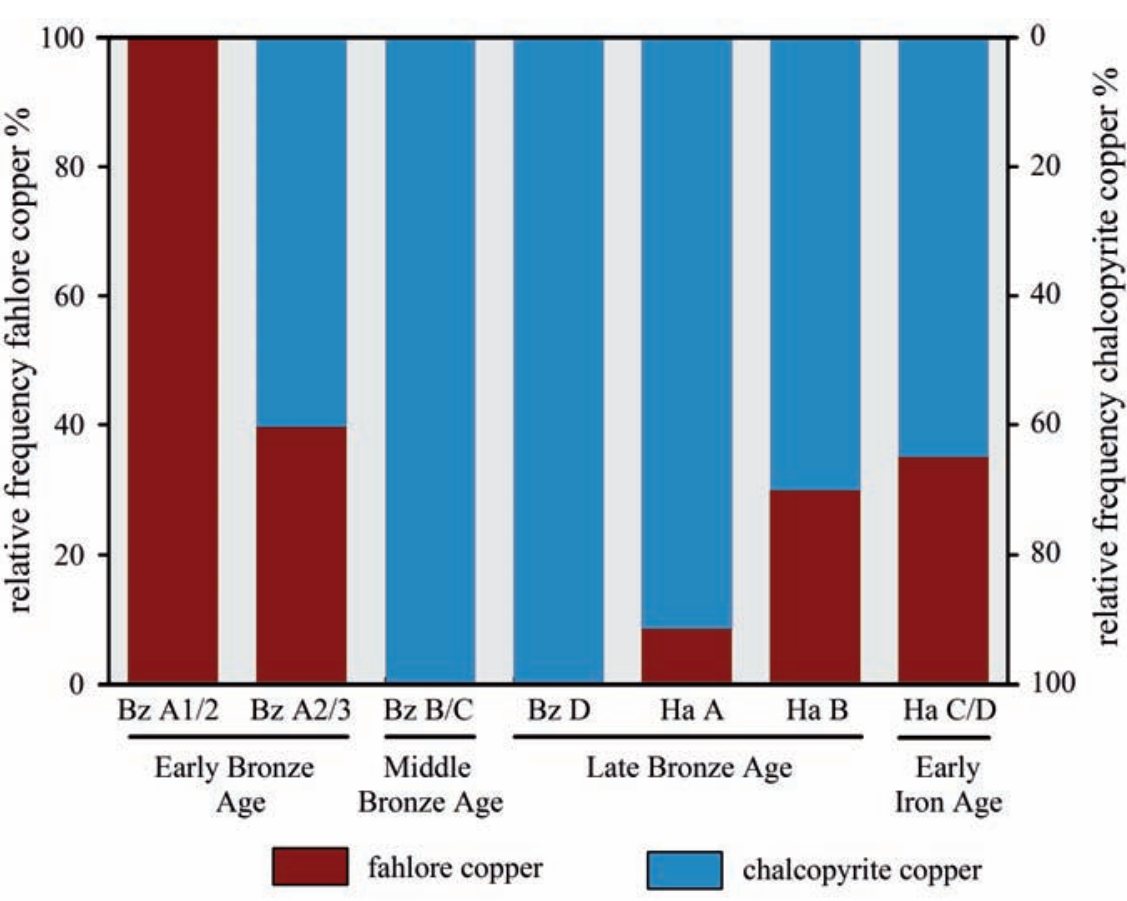

Figure 6. Use of fahlore copper and copper from chalcopyrite produced in the eastern Alpine region through time. This estimation is based on the composition of about 1200 prehistoric artifacts from Tyrol, Salzburg and southern Bavaria.

\section{Use of ores trough time}

In the Early Bronze Age, two main varieties of copper occur: fahlore copper with high nickel contents and fahlore copper with low nickel. The latter material is associated with local types of ingots (Ösenringe). Fahlore copper with nickel is the most important and common material in Central Europe but not in the investigated eastern Alpine area. Here the fahlore copper with very low nickel contents is the most common metal, whose impurity patterns are comparable with the fahlore deposits of the Inn valley (Figure 6). This underlines the importance of these deposits for the metal production of the Early Bronze Age. By the end of this and in the following period, a new variety of copper with lower concentrations of impurities appeared, which was smelted from chalcopyrite ores. The impurity patterns of these metal objects match the ores from the Mitterberg district in Salzburg. This may indicate that the technology of smelting chalcopyrite was developed in the Early Bronze Age, probably in the Mitterberg area. This relatively pure copper replaced the fahlore type almost completely. In the Late Bronze Age, the exploitation of ores changed again with production of fahlore copper resumed at Schwaz and Brixlegg. This high-impurity metal was probably mixed with copper smelted from chalcopyrite in order to reduce the negative effects of high arsenic and antimony contents.
Therefore, most artifacts of the Late Bronze Age show mixed impurity patterns. The reason for the resumption of mining fahlores in the Late Bronze Age might be a rising demand for copper which could not be covered by the chalcopyrite mines alone. Another reason could also be a decline of chalcopyrite mining due to depletion of the ore bodies near the surface. The metallurgy in the Early Iron Age is based on the traditions and metal industries of the Late Bronze Age. The metal composition of most artifacts corresponds with the artifacts of the Late Bronze Age, most artifacts show mixed impurity patterns (fahlore/chalcopyrite).

\section{References}

Bernhard J, 1965. [Die Mitterberger Kupferkieslagerstätte. Erzführung und Tektonik]. [Article in German]. Jahrbuch der Geologischen Bundesanstalt 109:3-90.

Eibner C, 1994. [Die Pongauer Siedlungskammer und der Kupferbergbau in der Urzeit]. In: W. Günther, C. Eibner, A. Lippert, W. Paar (eds.) [5000 Jahre Kupferbergbau Mühlbach am Hochkönig]. [Book in German]. Bischofshofen, Mühlbach, pp 11-26. mittleren Bronzezeit bei Jochberg (Nordtirol)]. In: G. Weisgerber, G. Goldenberg (eds.) [Alpenkupfer]. [Book in German]. Der Anschnitt, Bochum, pp 165-76.

Gstrein P, 1988. [Geologie, Mineralogie und Bergbau des Gebietes um Brixlegg]. In: S. Landmann (ed.) [Brixlegg, eine Tiroler Gemeinde im Wandel der Zeiten]. [Book in German]. Brixlegg, pp 11-62,.

Gstrein P, 1989. [Die Silberkammern von Schwaz, Tirol]. [Book in German]. Bode Verlag, Haltern, 56 pp.

Höppner B, Bartelheim M, Huijsmans M, Krauss R, Martinek K-P, Pernicka E, Schwab R, 2005. Prehistoric copper production in the Inn valley (Austria), and the earlierst copper in central Europe. Archaeometry 47:295-318.

Junghans S, Sangmeister E, Schröder M, 1968. [Kupfer und Bronze in der frühen Metallzeit Europas. Die Metallgruppen beim Stand von 12000 Analysen]. [Article in German]. Studien zu den Anfängen der Metallurgie 2:1-3.

Junghans S, Sangmeister E, Schröder M, 1974. [Kupfer und Bronze in der frühen Metallzeit Europas]. Studien zu den Anfängen der Metallurgie 2:4.

Krause R, 2003. Studien zur kupfer- und frühbronzezeitlichen Metallurgie zwischen Karpatenbecken und Ostsee. Verlag Marie Leidorf ed., Rahden.

Lutz J, Pernicka E, Pils R, Steiner M, Vavtar F, 2009. [Geochemische Charakterisierung der Erzvorkommen am Mitterberg und in Kitzbühel]. In: K. Oeggl, M. Prast (eds.) [Die Geschichte des Bergbaus in Tirol und seinen angerenzenden Gebieten]. [Book in German]. Innsbruck University Press, Silbertal, pp 175-81.

Oeggl K, Mathis F, Moser J, Schneider I, Leitner W, Tomedi G, Stöllner T, Krause R, Pernicka E, Tropper P, Schibler J, Nicolussi K, Hanke K, 2008. The history of mining activities in the Tyrol and adjacent areas: impact on environment and human societies (HiMAT). Antiquity 82:317.

Pittioni R, Preuschen E, 1937. [Untersuchungen im Bergbaugebiet Kelchalpe bei Kitzbühl, Tirol]. [Article in German]. Mitteilungen der prähistorischen Kommission 3:1-159.

Rieser B, Schrattenthaler H, 2000. [Urgeschichtlicher Kupferbergbau im Raum Schwaz-Brixlegg, Tirol]. [Article in German]. Archaeol Austr 82/83:135-79.

Sperber L, 2004. [Zur Bedeutung des nördlichen Alpenraumes für die spätbronzezeitliche Kupferversorgung in Mitteleuropa]. In: G. Weisgerber, G. Goldenberg (eds.) [Alpenkupfer]. [Book in German]. Der Anschnitt, Bochum, pp 303-45. 
Töchterle U, Goldenberg G, Tomedi G, 2010. The Late Neolithic to Middle Bronze Age Settlement on the Kiechelberg/Thauer (North Tyrol, Austria): raw materials and trade relations. In: Anreiter et al. (eds.) Mining in European history and its impact on environment and human societies. Proceedings for the $1^{\text {st }}$ Mining in European History-Conference of the SFB HiMAT, 12-15 November 2009, Innsbruck University Press, Innsbruck, pp 339-44.

Tomedi G, 2001. [Gedanken zur Interpretation des Schatzfundes vom Moosbruckschrofen am Piller]. [Book in German]. ArchaeoTirol, Wattens, pp 76-90.

Weber L, 1997. [Metallogenetische Karte Österreichs 1:500 000 unter Einbeziehung der Industrieminerale und Energierohstoffe. Handbuch der Lagerstätten und Erze, Industrieminerale und Energierohstoffe Österreichs. Erläuterungen zur metallogenetischen Karte]. [Book in German]. Geologische Bundesanstalt, Vienna, 607 pp.

Weber L, Pausweg F, Medwenitsch W, 1971. [Zur Mitterberger Kupfervererzung im
Südrevier (Arthurstollen)]. [Article in German]. Mitteilungen der Geologischen Gesellschaft in Wien 64:209-18.

Weber L, Pausweg F, Medwenitsch W, 1972. [Zur Mitterberger Kupfervererzung (Mühlbach/Hochkönig)]. [Article in German]. Mitteilungen der Geologischen Gesellschaft in Wien 65:137-58.

Zschocke K, Preuschen E, 1932. [Das urzeitliche Bergbaugebiet von MühlbachBischofshofen]. [Book in German]. Materialien zur Urgeschichte Österreichs, Wien. 